\title{
HOW TO BUILD MANUAL FOR KEY PERFORMANCE INDICATORS - KPI
}

\author{
NAgYOVA, A. \& PACAIOVA, H.
}

Abstract: Process performance measurement includes all activities, which present objective and detailed information about process performance. The key to the business success is related to good management information. Key Performance Indicators are quantifiable aspects that reflect the critical success factors of an organization and can be used for all types and in all areas of business: IT (information technology), construction, engineering, risk management, supply chain, safety, quality, manufacturing, financial management, sales, etc. The main goal is to find proper indicators for particular processes and find methodology that helps to identify those indicators.

Key words: performance, effective, improvement, quality
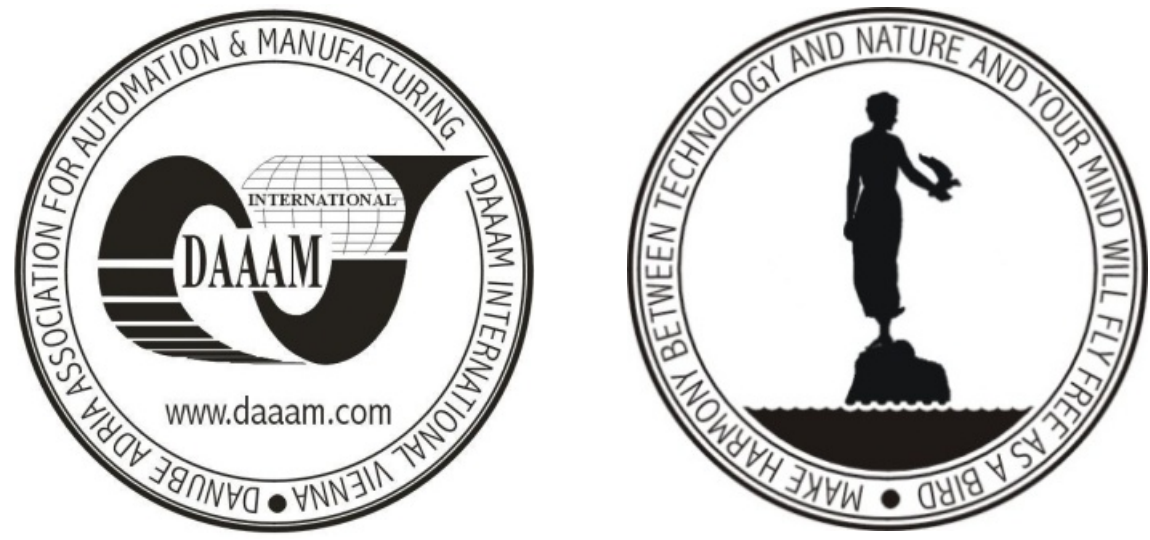

Authors' data: Ing. Nagyova, A[nna]; Assoc. Prof. Ing. Pacaiova, H[ana], Technical University of Kosice, Letna 9, 042 00, Kosice, Slovakia, a.nagyova@tuke.sk,pacof@centrum.sk,

This Publication has to be referred as: Nagyova, A[nna] \& Pacaiova, H[ana] (2009). How to Build Manual for Key Performance Indicators - KPI, Chapter 15 in DAAAM International Scientific Book 2009, pp. 135-142, B. Katalinic (Ed.), Published by DAAAM International, ISBN 978-3-901509-69-8, ISSN 1726-9687, Vienna, Austria

DOI: 10.2507/daaam.scibook.2009.15 